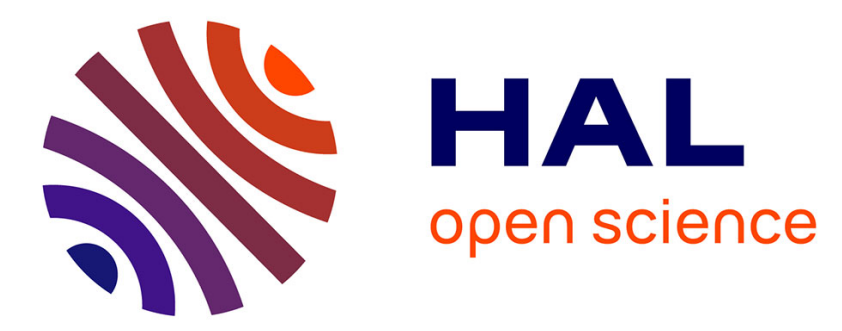

\title{
New Chinese psocids from Eocene Fushun amber (Insecta: Psocodea)
}

Qingqing Zhang, André Nel, Dany Azar, Bo Wang

\section{To cite this version:}

Qingqing Zhang, André Nel, Dany Azar, Bo Wang. New Chinese psocids from Eocene Fushun amber (Insecta: Psocodea). Alcheringa, 2016, 40 (3), pp.366 - 372. 10.1080/03115518.2016.1144952 . hal01393524

\section{HAL Id: hal-01393524 https://hal.sorbonne-universite.fr/hal-01393524}

Submitted on 7 Nov 2016

HAL is a multi-disciplinary open access archive for the deposit and dissemination of scientific research documents, whether they are published or not. The documents may come from teaching and research institutions in France or abroad, or from public or private research centers.
L'archive ouverte pluridisciplinaire HAL, est destinée au dépôt et à la diffusion de documents scientifiques de niveau recherche, publiés ou non, émanant des établissements d'enseignement et de recherche français ou étrangers, des laboratoires publics ou privés. 


\section{New Chinese psocids from Eocene Fushun amber (Insecta:}

\section{Psocodea)}

QING-QING ZHANG, NEL ANDRÉ, AZAR DANY, and BO WANG

ZhANG, Q.-Q., ANDRE, N., DANY, A. \& WANG, B. New Chinese psocids from Eocene Fushun amber (Insecta: Psocodea).

Qingqing Zhang [qqzhang@nigpas.ac.cn] and Bo Wang [bowang@nigpas.ac.cn], State Key Laboratory of Palaeobiology and Stratigraphy, Nanjing Institute of Geology and Palaeontology, Chinese Academy of Sciences, Nanjing 210008, China. University of the Qingqing Zhang also affiliated with Chinese Academy of Sciences, Beijing 100049, China. AndréNel[anel@mnhn.fr] and Dany Azar [Azar@mnhn.fr], Institut de Systématique, Évolution, Biodiversité, ISYEB - UMR 7205 - CNRS, MNHN, UPMC, EPHE, Muséum national d'Histoire naturelle, Sorbonne Universités, 57 rue Cuvier, CP 50, Entomologie, F75005, Paris, France. Dany Azar also affiliated with Lebanese University, Faculty of Sciences II, Department of Natural Sciences, Fanar, Fanar - Matn - P.O. Box 26110217, Lebanon. Bo Wang also affiliated with Key Laboratory of Zoological Systematics and Evolution, Institute of Zoology, Chinese Academy of Science, Beijing 100101, China.

Corresponding authors: Qingqing Zhang (qqzhang@nigpas.ac.cn), Nel André (anel@mnhn.fr)

Two new Psocodea, Sinopsyllipsocus fushunensis gen. et sp. nov. and Eotriplocania sinica gen. et sp. nov., are described from Eocene amber in Fushun City of China. They are 
distinctly different from all known Psocodea from Fushun amber in their three-segmented tarsi. S. fushunensis is the second unequivocal fossil of Psyllipsocidae. E. sinica is the first Asiatic and oldest representative of the Neotropical family Ptiloneuridae, and reveals a formerly global distribution of the family. The discovery of these two families in Eocene Fushun amber suggests a rather warm palaeoclimate for the Fushun amber locality.

Key words: Insecta, Psocodea, Fushun amber, China, Paleogene

FUSHUN, a city located in northeastern China, Liaoning Province, yields a unique amber biota from lower Eocene deposits (Fig. 1). Fushun amber comes from the layers of the West Opencast Coalmine ( $41^{\circ} 50^{\prime} \mathrm{N}, 123^{\circ} 54^{\prime} \mathrm{E}$ ), which is the largest opencast coalmine in Asia. The mining district in the Fushun basin contains the Palaeocene Laohutai and Lizigou formations and the Eocene Guchengzi, Jijuntun, Xilutian, and Gengjiajie formations(see Wang et al. 2014). The amber-bearing Eocene Guchengzi Formation includes thick coal beds intercalated with carbonaceous shale (Wu et al. 2000, Meng et al. 2012, Wang et al. 2014). Fushun amber comes from the middle and upper coal beds of the Guchengzi Formation, which have been assigned an early-middle Ypresian age (50-53 $|\mathrm{Ma}|)$ constrained by the paleofloras, paleomagnetic considerations, and isotopic dating (Wang et al. 2010, Quan et al. 2011). Fushun amber contains the only Paleogene Asian (Laurasia-originated) arthropod biota that has sufficiently numerous and diverse fossils to permit detailed investigation (Wang et al. 2014). The palaeoclimate in the early Eocene in Fushun is reconstructed as moist subtropical, with variability in seasonal precipitation (very probably a monsoonal system), with dry and wet seasons (Quan et al. 2011, 2012, Wang et al. 2013).

The Chinese Fushun amber is known for its entomofauna since the work of Hong (2002). However, interest in this fauna has not been great until the recent overview paper of Wang et 
al. (2014). The insect fauna proved very diverse with representatives of Diptera, Hymenoptera, Coleoptera, Thysanoptera, Hemiptera and Psocodea. Here we described two new psocids that are of great interest for the biogeography of these groups and palaeoclimate of the Fushun amber locality.

\section{Materials and methods}

The specimens are preserved in pieces of relatively clear, yellow amber. The amber pieces containing the inclusions were cut, shaped, and polished. Then they were mounted between two coverslips with a Canada balsam medium as described by Azar et al. (2003) before being examined and photographed. The fossils were examined and measured with incident light using an Olympus SZX9 and Leitz Wetzlar binocular microscopes.

The general characteristics of Fushun amber and its geological context were provided by Wang et al. (2014). We follow the wing venation nomenclature of Nel et al. (2012) and the body part nomenclature of Mockford (1993). Abbreviations for wing venation are as follows: ScP subcosta posterior; RA radius anterior; RP radius posterior; r-rs crossvein between RA and RP; MA median anterior; MP median posterior; CuA cubitus anterior; CuP cubitus posterior, cua-cup brace between $\mathrm{CuA}$ and $\mathrm{CuP}$; A1, A2 anal veins.

\section{Systematic palaeontology}

Suborder TROGIOMORPHA Roesler, 1940

Family PSYLLIPSOCIDAE Enderlein, 1911

Sinopsyllipsocus gen. nov.

Type species. Sinopsyllipsocus fushunensis gen. et sp. nov. 
Etymology. Named after the Latin for China, and Psyllipsocus. Gender masculine.

Diagnosis. Psyllipsocid with secondary annulation on antennae; 22 flagellomeres; long sensillum on mx2; no large sensillum or smaller ones near distal end of mx4; macropterous, with numerous veins on wings, forewing margin almost glabrous, veins with few dorsal setae disposed in one row; ScP not reaching radius; areola postica present, narrow elongate.

Sinopsyllipsocus fushunensis sp. nov. (Figs 2, 3)

Material. Holotype specimen 11036, deposited in the Nanjing Institute of Geology and Palaeontology, China.

Etymology. Named after Fushun City.

Age and occurrence. Early Eocene; Guchengzi Formation, West Opencast Coalmine, Fushun, Liaoning, China.

Diagnosis.

Description. Body 2.0 mm long; head 0.4 mm long, 0.65 mm wide; vertex without setae, large, distance between eyes $0.4 \mathrm{~mm}$, ratio of distance between eyes and greatest width of postclypeus 2:1; anterior part of head without setae; vertical epicranial suture distinct but anterior arms less distinct; frons large; postclypeus gibbous but not very prominent; ocelli disposed in triangle far from compound eyes, anterior ocellus as large as others; eye hairless, 
rather large, $0.15 \mathrm{~mm}$ diameter, reaching level of vertex; lacinia present but indistinct; mx2 with a long conical sensillum; mx4 apically broadened, with several short setae but no large sensillum, with smaller sensillum near distal end (Fig. 2C, D); scape $0.08 \mathrm{~mm}$ long, pedicel $0.08 \mathrm{~mm}$ long, both distinctly broader than flagellomeres; 22 flagellomeres (f), annulated, with two rows of three rather long setae, f1 and f2 $0.01 \mathrm{~mm}$ long, f3 and f4 $0.06 \mathrm{~mm}$ long, f5 and more distal flagellomeres nearly all $0.07 \mathrm{~mm}$ long (Fig. 3C).

Dorsal surface of thorax apparently bare; thorax deformed, $0.5 \mathrm{~mm}$ long, $0.45 \mathrm{~mm}$ wide; meso- and metanotum not raised above level of head. Abdomen deformed, $1.1 \mathrm{~mm}$ long, 0.3 mm wide; genital organs not visible (Fig. 2A, B).

Forewing hyaline, $2.4 \mathrm{~mm}$ long, $0.8 \mathrm{~mm}$ wide, ratio of forewing length to width $3: 1$; wing elongate, apex rounded; basal part of ScP not reaching radius and distally evanescent, 0.25 mm long; ScP distinct, 1.4 mm long, directed posteriorly; pterostigmal area not sclerotized; base of RP nearly perpendicular to R and M; r-rs crossvein present; RP and M fusion short, 1.5 mm long; RP divided into two apical branches; $\mathrm{M}$ with three branches; CuA divided into two branches $\mathrm{CuAa}$ and $\mathrm{CuAb}, \mathrm{Cu} 1 \mathrm{a} 0.8 \mathrm{~mm}$ long; vein $\mathrm{CuP}$ and $\mathrm{A} 1$ distally fused in a nodulus (Fig. 3B); no A2; wing membrane bare, only a few setae disposed in one row on main veins; very few setae on $C$ but no setae on other parts of wing margin (Fig. 3A, D).

Hindwing hyaline, $2.0 \mathrm{~mm}$ long, $0.65 \mathrm{~mm}$ wide, rather narrow, elongate, but apex rounded; ScP not visible; basiradial cell closed, narrow and elongate, triangular; RP basally fused with $\mathrm{M}$ in a common stem; both RP and M with two distal branches; CuA simple (Fig. 3A, E). Legs with tarsi three-segmented; claws with very small single preapical tooth; short setae on legs, two short apical spurs on posterior tibia.

Discussion. According to the key to the psocopteran families of Smithers (1990), Sinopsyllipsocus fushunensis falls in the couplet coming out as 
Psyllipsocidae/Prionoglarididae because of the following combination of characters:

macropterous form; tarsi three-segmented; body and wings lacking flattened scales; forewing venation complex; pterostigmal area not opaque; nodulus present; only one anal vein in forewing; lacinia present. The presence of a long, conical sensillum on mx2 favours affiliation with Prionoglarididae, but the wing venation of our fossil better corresponds to that of Psyllipsocidae in that the ScP does not reach the radius, and the areola postica is narrow and elongate (see Smithers 1972, Lienhard 2000). According to Mockford (1993) and Baz \& Ortuño (2000), the presence of more than 20 antennal flagellomeres implies an attribution to Trogiomorpha. The Psocatropetae may possess or lack a sensillum on mx2; they can have annulation or lack it on the antennae. Our fossil differs from Psyllipsocus and all other Psyllipsocidae in the presence of secondary annulation on the antennae plus the presence of a sensillum on mx2 (Smithers 1972).

More precisely, according to the key to genera of Smithers (1990, p25), S. fushunensis would be closely affiliated with Psyllipsocus because of the following characters: macropterous form with numerous veins on wings; forewing margin almost glabrous; and veins with few dorsal setae disposed in one row. In the key to Nearctic genera of Mockford (1993, p46-47), it would also be linked closely to Psyllipsocus because of the forewing being large, with RP and M branched distally, forewing broad with a ratio of forewing length to width 3.44:1, vertex broad, and meso- and metanotum not raised above the level of the head. Dorypteryx Aaron, 1883 has reduced forewings. S. fushunensis cannot be attributed to Psocatropos Ribaga, 1899 and Pseudorypteryx García-Aldrete, 1984 because the forewing CuA is forked into CuAa and CuAb. Furthermore, S. fushunensis does not belong to Pseudorypteryx because it lacks a large sensillum or smaller ones near the distal end of mx4 (García-Aldrete 1984, Mockford 1993, p49). Khatangia Vishniakova, 1975, which is based on one species, $K$. inclusa Vishniakova, 1975, from the Late Cretaceous Taimyr amber, has a 
forewing venation similar to that of Psyllipsocus (Vishniakova 1975). Sinopsyllipsocus fushunensis differs from Khatangia in the presence of a nodulus and, in its hindwing, RP being basally fused with $\mathrm{M}$ in a common stem and the basiradial cell consequently triangular, as in extant Psyllipsocus.

The lack of precise information on the structure of the lacinia, female genital valvulae and colouration of body and appendages of $S$. fushunensis prevents any detailed comparison to the modern species of Psyllopsocus. Smithers (1972, p53) indicated that the modern Psyllopsocus spp. have antennae with 22 segments or more (see also New \& Lee 1991), as in S. fushunensis.

To date four fossils have been assigned to Psyllipsocidae: Psyllipsocus eocenicus Nel et al., 2005 (lowermost Eocene French Oise amber), ?Psyllipsocus banksi Cockerell, 1916 (midCretaceous Burmese amber), a ”Psyllipsocus sp. (nymph)“ from Lower Miocene Mexican amber (Mockford 1969), and Khatangia inclusa Vishniakova, 1975 (Late Cretaceous Taimyr amber) but the last three systematic positions are dubious and require revision. Psyllipsocus eocenicus Nel et al., 2005 differs from S. fushunensis in the presence of only 18 flagellomeres instead of 20. ?Psyllipsocus banksi Cockerell, 1916 from upper Albian Burmese amber, was listed by Spahr (1992) and Ross \&York (2000, p12), among others, but has never been critically evaluated. Its original attribution was based on the opinion of Nathan Banks: 'The Psocid you figure must be close to Psyllipsocus de Selys; ...' (Cockerell 1916). The original description and figures lack several characters diagnostic of the family and genus. The type specimen needs a redescription before any definite attribution of this taxon can be made. Mockford (1969) described a 'Psyllipsocus sp. (nymph)' from the Miocene Mexican amber.

Infraorder Epipsocetae Pearman, 1936

Family PTILONEURIDAE Eertmoed, 1973 
Eotriplocania gen. nov.

Type species. Eotriplocania sinica gen. et sp. nov.

Etymology. Named after the Eocene period and Triplocania Roesler, 1940. Gender feminine.

Diagnosis. This fossil genus is characterized by the following combination of characters: 11 flagellomeres; crossvein between Rs and M in forewing very short; areola postica high with apex rounded, nearly as wide as long; forewing 2A joining wing margin; no crossveins between A1 and wing margin; forewing M three-branched; stem of Rs basal of crossvein rs-m long; rs-m very short; hindwing $M$ single-branched; labral sclerite incomplete, not reaching anterior margin of labrum.

Eotriplocania sinica sp. nov. (Figs 4, 5)

Material. Holotype specimen 12048, deposited in the Nanjing Institute of Geology and Palaeontology, China.

Age and occurrence. Early Eocene; Guchengzi Formation, West Opencast Coalmine, Fushun, Liaoning, China.

Etymology. Named after the Latin for China.

Diagnosis. 
Description. Body $1.56 \mathrm{~mm}$ long; head elongate, $0.42 \mathrm{~mm}$ long, $0.45 \mathrm{~mm}$ wide; mandible short; eyes not stalked on a long dorsolateral extension of head capsule; dorsal border of epistomal suture present (Fig. 4C, D); antennae with scape $0.1 \mathrm{~mm}$ long, pedicel $0.12 \mathrm{~mm}$ long, both distinctly broader than flagellomeres; 11 preserved flagellomeres without any annulation but with long setae disposed into two ventral rows; first flagellomere very long, $0.45 \mathrm{~mm}$ long; not placoid sensilla on flagellomeres; pair of setae at base of ocellar group; labial palpus triangular; labral sclerites present but with anterior ends not joined by a sclerotic strip; lacinial tip with outer cusp more developed than inner cusp. Thorax deformed, $0.45 \mathrm{~mm}$ long; meso- and metanotum not raised above level of head. Abdomen deformed, $0.75 \mathrm{~mm}$ long; female genital organs hardly visible.

Wings hyaline, without flattened scales; forewing $1.8 \mathrm{~mm}$ long, $0.59 \mathrm{~mm}$ wide; margin and veins glabrous; costa not thickened in margin of pterostigma; pterostigmal area opaque, with microsetae, $0.45 \mathrm{~mm}$ long, $0.12 \mathrm{~mm}$ wide; pterostigma 3.7 times as long as wide; nodus present; veins Rs and M connected by a short crossvein; areola postica free, $0.25 \mathrm{~mm}$ long, $0.14 \mathrm{~mm}$ wide, only 1.8 times as long as wide; $\mathrm{CuAa}$ and $\mathrm{CuAb}$ separated near posterior wing margin; two anal veins (Fig. 5A, C). Hindwing $1.4 \mathrm{~mm}$ long, $0.42 \mathrm{~mm}$ wide; anal vein long, parallel to wing margin; very small setae on veins Rs and M; row of fine setae on proximal end of costal margin (Fig. 5B, D).

Legs with tarsi three-segmented; pretarsal claw with a preapical denticle; pulvillus of pretarsal claw straight and pointed (Fig. 4E); ctenidiobothria present on t1 and t2 of female mid- and hind leg.

Discussion. Eotriplocania sinica can be attributed to the Psocomorpha due to the presence of 11 flagellomeres without any annulation, the presence of a nodus on the forewing, and a 
sclerotized pterostigma. It can be attributed to the Epipsocetae on the basis of the following apomorphies, as defined by Casasola-González (2006): a pair of setae at the base of the ocellar group; labral sclerites present; lacinial tip with outer cusp more developed than inner cusp; ctenidiobothria present on $\mathrm{t} 1$ and t2 of female hind leg; presence of a second anal vein (A2) in forewing; very small setae on veins Rs and $\mathrm{M}$ of hindwing; veins Rs and $\mathrm{M}$ of forewing with a (short) cross-vein between them.

The character state 'row of fine setae on proximal end of costal margin of macropterous hind wing present' is an apomorphy of the clade [Ptiloneuridae, Spurostigma + Cladiopsocus (Cladiopsocidae) and Epipsocidae] whereas the three plesiomorphic character states 'pulvillus of pretarsal claw straight', 'pulvillus apex pointed' and 'pterostigma only 3.7 times as long as wide’ would exclude Eotriplocania sinica from the family Dolabellopsocidae. The rather long pterostigma and the anterior ends of labral sclerites not joined by a sclerotic strip are characters of Ptiloneuridae rather than of [Spurostigma+Cladiopsocus (Cladiopsocidae) and Epipsocidae].

According to the key to the psocopteran families of Smithers (1990), Eotriplocania sinica also belongs to Ptiloneuridae because of the following combination of characters: macropterous form, tarsi three-segmented, body and wings lacking flattened scales, forewing venation complex, pterostigmal area thickened, forewing with nodulus and two anal veins; head elongate, labrum with two ridges; forewing veins lacking spurs.

According to the keys to ptiloneurid genera of García-Aldrete (2006) and Azar et al. (2009), Eotriplocania sinica would fall near the two Neotropical genera Triplocania Roesler, 1940 and Belicania García-Aldrete, 2006 based on possession of the following characters: hindwing M single-branched; forewing 2A joining wing margin; no crossveins between A1 and wing margin; forewing areola postica high with apex rounded; labral sclerite incomplete, not reaching anterior margin of labrum; and forewing $M$ three-branched. The differences 
between Eotriplocania and the two Neotropical genera concern the structure of the hypandrium, a structure unknown in our fossil.

Eotriplocania sinica differs from genus Belicania in the Ptiloneuridae in the areola postica being shorter, nearly as long as wide. This fossil differs from all modern species of Triplocania in the Ptiloneuridae by its longer stem of Rs basal of crossvein rs-m. Moreover, most Triplocania species have a longer rs-m than in this fossil, except T. magnifica Roesler, 1940.

\section{Discussion}

Sinocladiopsocus fossilis and Eotriplocania sinica differ from all the Psocodea described by Hong (2002) from the Fushun amber in their three-segmented rather than two-segmented tarsi. S. fushunensis is the second unequivocal fossil of Psyllipsocidae, and the other is from the Eocene French Oise amber. Modern psyllipsocids live in caves, on rock surfaces, and among dead leaves, and they are restricted to the tropical regions of South America, Africa and Asia, with a few species from North America and one cosmopolitan (García-Aldrete 1997). E. sinica is the oldest record of Ptiloneuridae, of which extant species are all Neotropical. The fossil record of Ptiloneuridae is extremely rare. Until now, only two fossil species have been described from Colombian copal (Azar et al. 2009). Our fossil is the first Asiatic representative of Ptiloneuridae, and reveals a formerly global distribution of the family (Fig. 6). The poor record of the family, however, precludes any detailed speculation about dispersal patterns. In summary, both families are nowdays distributed in tropical regions, and thus our findings suggest a rather warm palaeoclimate for the Fushun amber locality (Wang et al. 2010, Quan et al. 2011).

\section{Acknowledgements}


We are grateful to Prof. E.A. Jarzembowski for improving the English language of the manuscript. This research was supported by the National Basic Research Program of China (2012CB821900), and National Natural Science Foundation of China (41572010, J1210006).

\section{References}

Aaron, S.F., 1883. Description of new Psocidae in the Collection of the American Entomological Society. Transactions of the American Entomological Society 9, 37-40. Azar, D., Perrichot, V., Néraudeau, D. \& Nel, A., 2003. New psychodids from the Cretaceous ambers of Lebanon and France, with a discussion of Eophlebotomus connectens Cockerell, 1920 (Diptera, Psychodidae). Annals of the Entomological Society of America 96, 117-126.

Azar, D., Nel, A. \& Waller, A., 2009. Two new Ptiloneuridae from Colombian copal (Psocodea: Psocomorpha). Denisia 26, 21-28.

BAZ, A. \& Ortuño, V.M., 2000. Archaeatropidae, a new family of Psocoptera from the Cretaceous amber of Álava, northern Spain. Annals of the Entomological Society of America 93, 367-373.

CASAsola-GONZÁLEZ, J.A., 2006. Phylogenetic relationships of the genera of Epipsocetae (Psocoptera: Psocomorpha). Zootaxa 1194, 1-32.

CoCKerell, T.D.A., 1916. Insects in Burmese amber. American Journal of Science 42, 135138.

Eertmoed, G., 1973. The phenetic relationships of the Epipsocetae (Psocoptera): the higher taxa and the species of two new families. Transactions of the American Entomological Society 99, 393-414.

Enderlein, G., 1911. Die Fossilen Copeognathen und ihre Phylogenie. Palaeontographica $58,279-360$. 
GarCíA-Aldrete, A.N., 1984. The Trogiomorpha (Psocoptera), of Chamela, Jalisco, Mexico. Folia Entomologica Mexicana 59, 25-69.

GarcíA-ALdrete, A.N., 1997. A new species of Psyllipsocus (Psocoptera Psyllipsocidae) from Belize. Redia 80, 1-5.

GarcíA-AldRete, A.N., 2006. New genera of Psocoptera (Insecta), from Mexico, Belize and Ecuador (Psoquillidae, Ptiloneuridae, Lachesillidae). Zootaxa 1319, 1-14.

Hong, Y.C., 2002. Amber insects of China. Science and Technical Publishing House of Beijing, 653 pp. (Chinese)

LienHARD, C., 2000. A new genus of Prionoglarididae from a Namibian cave (Insecta: Psocoptera). Revue Suisse de Zoologie 107, 871-882.

Lienhard, C. \& Smithers, C.N., 2002. Psocoptera (Insecta): World catalogue and bibliography. Instrumenta Biodiversitatis 5, xli + 745 pp.

Meng, Q.T., Liu, Z.J., Bruch, A.A., LiU, R. \& Hu, F. 2012. Palaeoclimatic evolution during Eocene and its influence on oil shale mineralisation, Fushun basin, China. Journal of Asian Earth Sciences 45, 95-105.

MoCKFORD, E.L., 1969. Fossil insects of the Order Psocoptera from Tertiary amber of Chiapas, Mexico. Journal of Paleontology 43, 1267-1273.

MocKFORD, E.L., 1983. Systematics of Asiopsocidae (Psocoptera) including Pronotriopsocus amazonicus n. gen., n. sp. Florida Entomologist 66, 241-249.

MocKFord, E.L., 1993. North American Psocoptera (Insecta). Flora \& Fauna Handbook 10, $1-455$.

Nel, A., Prokop, J., De PloËG, G. \& Millet, J., 2005. New Psocoptera (Insecta) from the Lowermost Eocene amber of Oise, France. Journal of Systematic Palaeontology 3, 371391. 
Nel, A., Prokop, J., Nel, P., Grandcolas, P., Huang, D.Y., Roques, P., Guilbert, E., DostÁL, O. \& SzWEDO, J., 2012. Traits and evolution of wing venation pattern in paraneopteran insects. Journal of Morphology 273, 480-506.

New, T.R. \& LeE, S.S., 1991. An unusual new species of Psyllipsocidae (Psocoptera) from Malaysia. Oriental Insects 25, 117-119.

Quan, C., LiU, Y.S. \& Utescher, T., 2011. Paleogene evolution of precipitation in northeastern China supporting the middle Eocene intensification of the East Asian monsoon. Palaios 26, 743-753.

QuAn, C., LiU, Y.S. \& UTESChER, T., 2012. Paleogene temperature gradient, seasonal variation and climate evolution of northeast China. Palaeogeography, Palaeoclimatology, Palaeoecology 313-314, 150-161.

Ribaga, C., 1899. Descrizione di un nuovo genere e di una nuova specie di Psocidi trovato in Italia. Rivista di Patologia Vegetale 8, 156-158.

RoEsLer, R., 1940. Neue und wenig bekannte Copeognathengattungen. 1. Zoologischer Anzeiger 129, 225-243.

Ross, A.J. \& York, P.V., 2000. A list of type and figured specimens of insects and other inclusions in Burmese amber. Bulletin of the Natural History Museum Geology 56, 11-20.

Smithers, C.N., 1972. The classification and phylogeny of Psocoptera. Australian Museum Memoirs 14, 1-351.

Smithers, C.N., 1990. Keys to the families and genera of Psocoptera (Arthropoda, Insecta). Technical Reports of the Australian Museum 2, 1-82.

SpaHR, U. von, 1992. Ergänzungen und Berichtigungen zu R. Keilbachs Bibliographie und liste der Bernsteinfossilien, Klasse Insecta (Ausgenommen: “Apterygota”, Hemipteroidea, Coleoptera, Hymenoptera, Mecopteroidea). Stuttgarter Beiträge zur Naturkunde (B) 182, 1-102. 
Vishniakova, V.N., 1975. Psocoptera in Late Cretaceous insect-bearing resins from the Taimyr. Entomological Review 54, 63-75.

Wang, B., Rust, J., Engel, M.S., Szwedo, J., Dutta, S., Nel, A., FAn, Y., Meng, F.W., ShI, G.L., Jarzembowski, E.A., Wappler, T., Stebner, F., FAng, Y., MaO, L.M., Zheng, D.R. \& ZhANG, H.C., 2014. A diverse paleobiota in Early Eocene Fushun amber from China. Current Biology 24, 1610-1616.

Wang, Q., Ferguson, D.K., Feng, G.P., Ablaev, A.G., Wang, Y.F., Yang, J., Li Y.L. \& Li, C.S., 2010. Climatic change during the Palaeocene to Eocene based on fossil plants from Fushun, China. Palaeogeogr, Palaeoclimatol, Palaeoecol 295, 323-331.

WANG, D., Lu, S., HAN, S., Sun, X. \& QuAN, C., 2013. Eocene prevalence of monsoon-like climate over eastern China reflected by hydrological dynamics. Journal of Asian Earth Sciences 62, 776-787.

Wu, C.L., YANG, Q., Zhu, Z.D., LiU, G. \& LI, X., 2000. Thermodynamic analysis and simulation of coal metamorphism in the Fushun Basin, China. International Journal of Coal Geology 44, 149-168.

Yoshizawa, K. 2002. Phylogeny and higher classification of the suborder Psocomorpha (Insecta: Psocodea: 'Psocoptera'). Zoological Journal of the Linnean Society 136, 371400.

Yoshizawa, K. \& Johnson, K.P., 2014. Phylogeny of the suborder Psocomorpha: congruence and incongruence between morphology and molecular data (Insecta: Psocodea: 'Psocoptera'). Zoological Journal of the Linnean Society 171, 716-731.

\section{List of figures.}

Fig. 1. Map showing the location of Fushun city in northeastern of China. 
Fig. 2. Sinopsyllipsocus fushunensis gen. et sp. nov., holotype 11036. A, photograph of dorsal features; $\mathbf{B}$, photograph of ventral features. C, photograph of palp; $\mathbf{D}$, drawing of palp, arrow: long conical sensillum on mx2. Scale bars $=0.5 \mathrm{~mm}$ in $\mathrm{A}, \mathrm{B}$, and $=0.1 \mathrm{~mm}$ in $\mathrm{C}, \mathrm{D}$.

Fig. 3. Sinopsyllipsocus fushunensis gen. et sp. nov., holotype 11036. A, photograph of wings; B, photograph of nodulus; C, photograph of apical flagellomeres; D, drawings of wings. Scale bars $=0.5 \mathrm{~mm}$ in $\mathrm{A}, \mathrm{D}$, and $=0.1 \mathrm{~mm}$ in $\mathrm{B}, \mathrm{C}, \mathrm{D}$.

Fig. 4. Eotriplocania sinica gen. et sp. nov., holotype 12048. A, photograph of dorsal features; $\mathbf{B}$, photograph of ventral features; $\mathbf{C}$, photograph of front view of head; $\mathbf{D}$, drawing of front view of head; E, photograph of pretarsal claw; Scale bars $=0.5 \mathrm{~mm}$ in $\mathrm{A}, \mathrm{B},=0.1 \mathrm{~mm}$ in $\mathrm{C}$, $\mathrm{D}$, and $=0.01 \mathrm{~mm}$ in $\mathrm{E}$.

Fig. 5. Eotriplocania sinica gen. et sp. nov., holotype 12048. A, photograph of forewing; B, photograph of hindwing; $\mathbf{C}$, drawing of fore wing $\mathbf{D}$, drawing of hind wing; Scale bars $=0.5$ $\mathrm{mm}$.

Fig. 6. Map showing the distribution of fossil (red star) and Recent taxa of Ptiloneuridae (red color). 


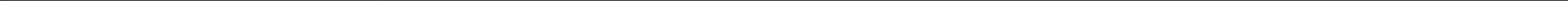


$A$

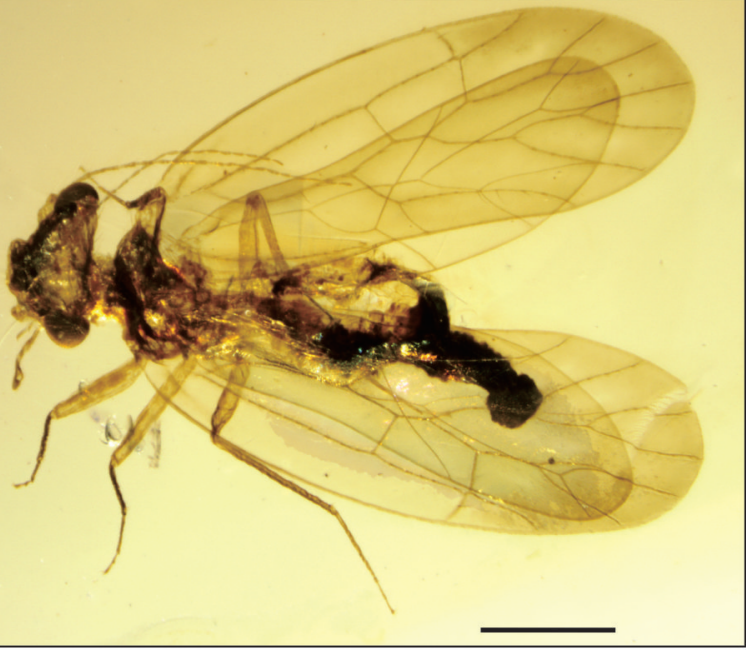

B

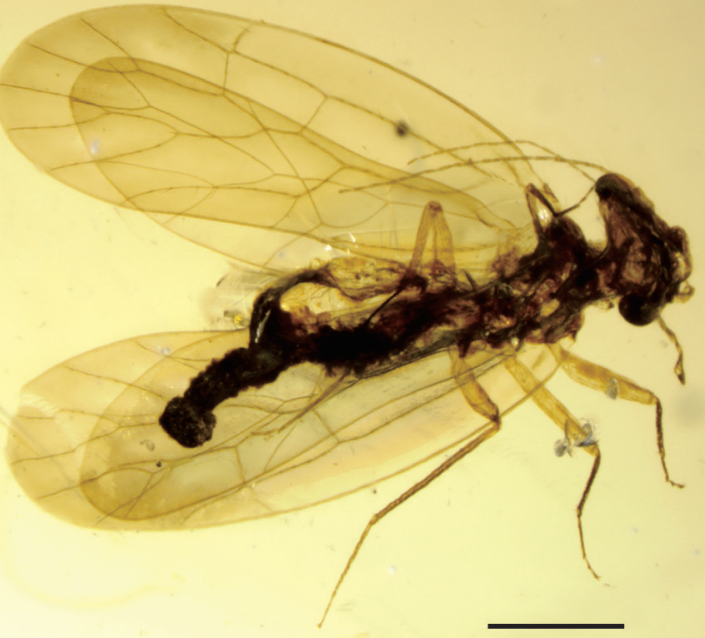

C

mosereas

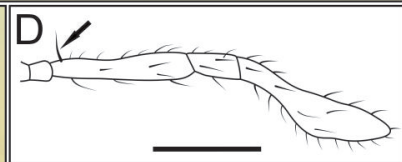




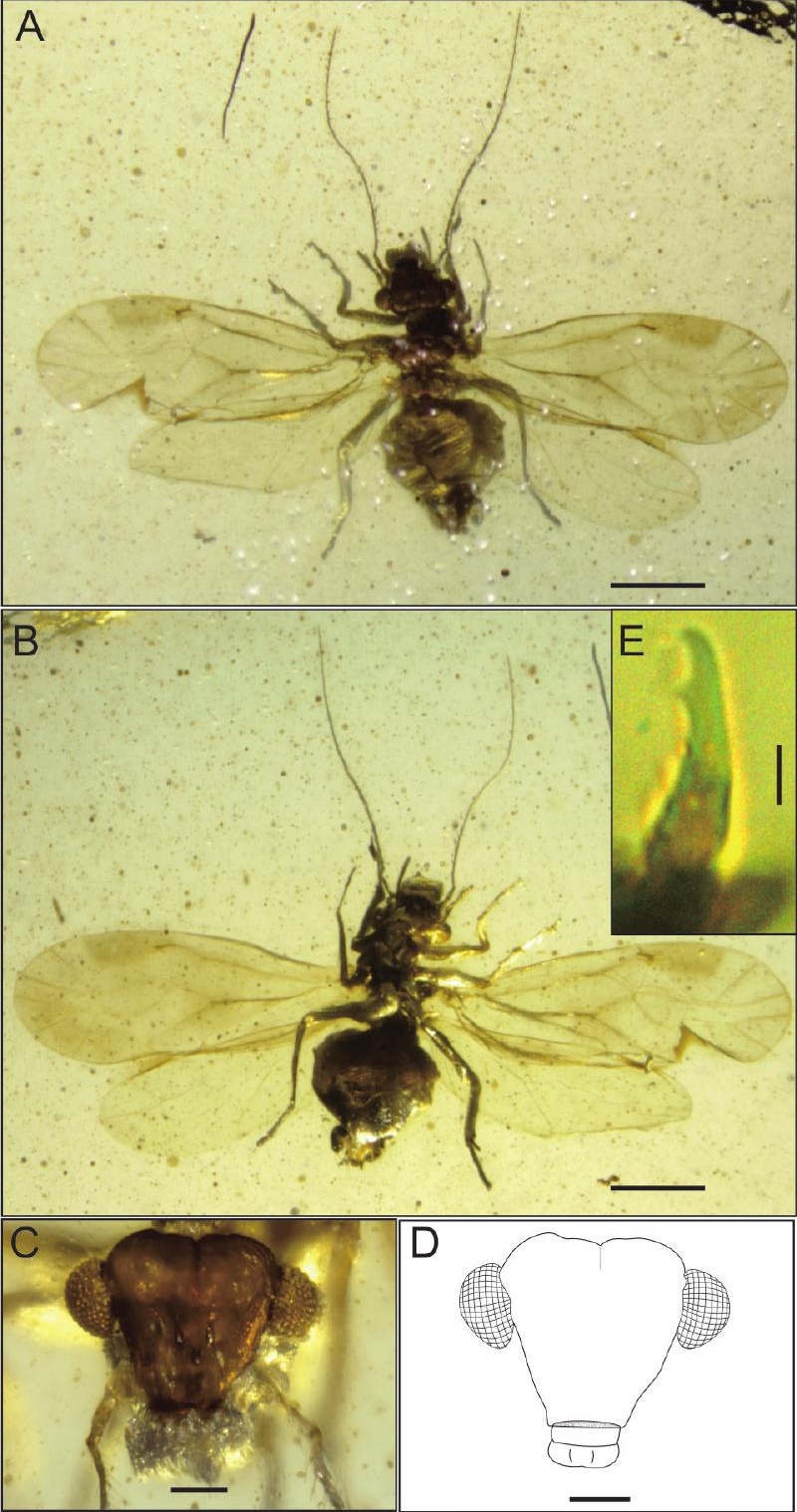


C

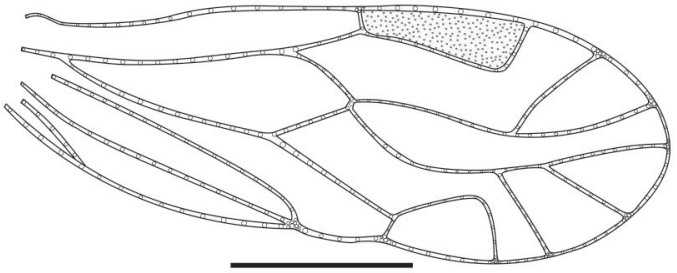

D

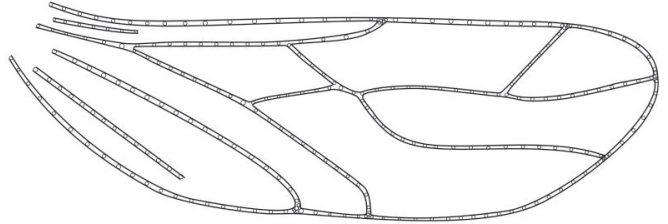




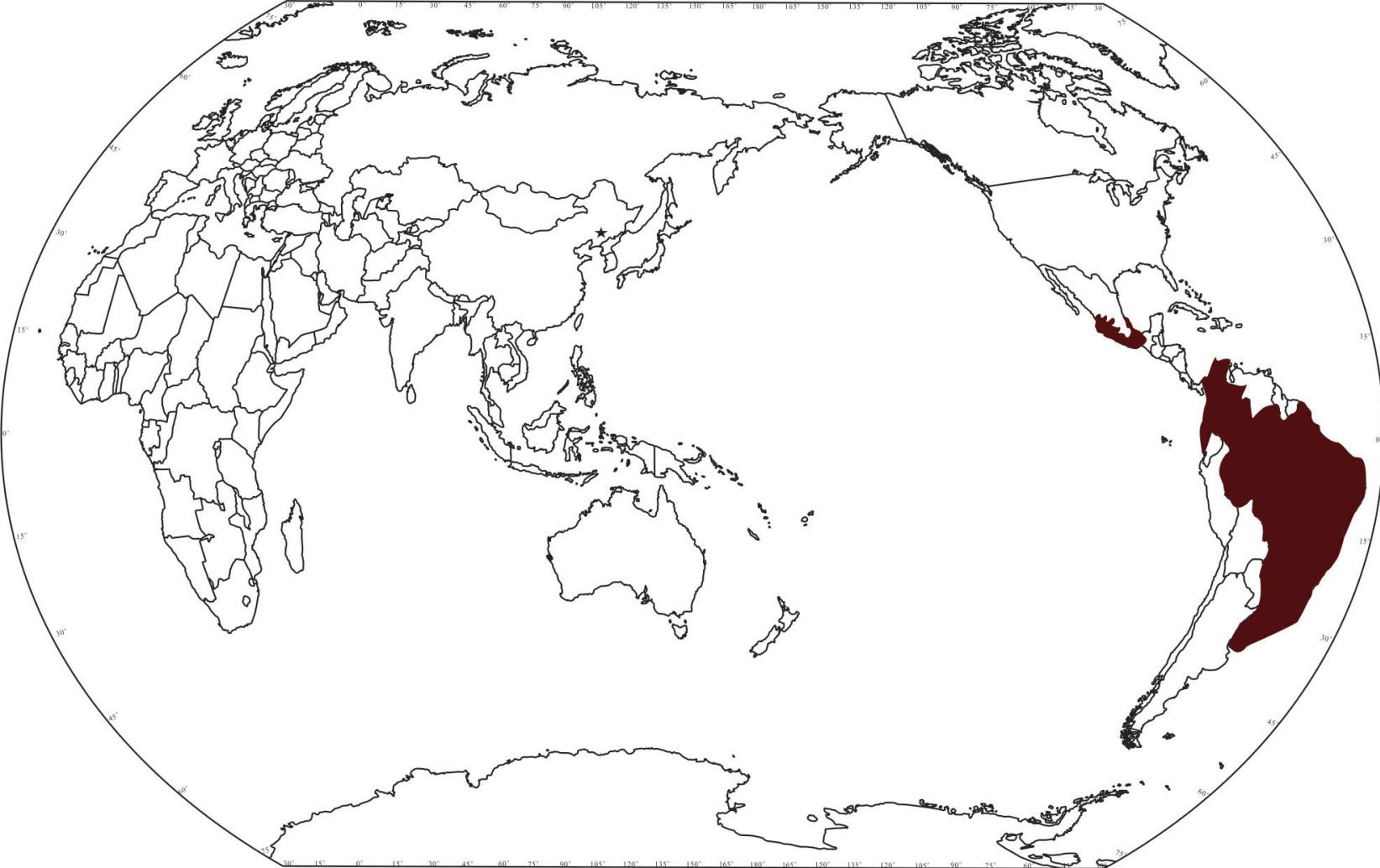

